\title{
APPLICATION OF ACCOUNTING LEARNING USING STANDARDS OF PSAK CONSERVATION OF IFRS IN MEDIUM SCHOOL ACCOUNTING VOCATIONAL SCHOOL
}

\author{
Khairani Sakdiah $^{1^{*}}$, Cita Ayni Putri Silalahi ${ }^{1}$ \\ ${ }^{I}$ Economic Education, Teacher Training Faculty, Muslim University Nusantara Al Washliyah, Medan, Indonesia \\ *Corresponding Author: ranihidayat72@gmail.com
}

\begin{abstract}
The purpose of education at the opening of the 1945 Constitution in the fourth paragraph was clearly explained that, to educate the life of the nation and participate in carrying out world order. In accordance with the goals and ideals of the nation, various fields of science are needed by the State. To be able to progress and develop in accordance with the needs of the State, we must also follow the existing regulations that are binding in the agreement of states. Likewise, there is no escape in accounting learning that must be applied in schools, both in universities and high schools, which are mainly vocational high schools (SMK). As an example of accounting subjects, Accounting is a field of applied science that is used to see the financial existence of both the state, agencies, companies and organizations and others. International Financial Reporting Standards (IFRS) is the making of accounting reports that are adjusted to the standards of international financial reports, and almost all parts of the world in this world of accounting reporting use the IFSR standard. Because of that, almost all companies are required to use these standards in terms of financial statements making, educators are also obliged and participate in teaching these standards to students, both in universities and schools that have accounting majors can also apply this as teaching materials that are not left behind. The indicators used to measure the application of accounting learning by using standards are IFRS convergence PSAK, namely: Viewing and observing the behavior of actions taken by teachers in schools that are the object of research, whether using IFRS convergence accounting standards in teaching to provide material to students and adjustments between kurukulum given by dina education. The population in this study were the Accounting Department teachers who were in Langkat Regency. Data collection techniques in this study were using interviews, observation, documentation and questionnaires. The research method used in this study is descriptive analysis. And the results obtained as a whole in this study are the absence of teachers who apply accounting learning by applying accounting using IFRS standards because there is no directive from the education office to enforce these standards.
\end{abstract}

Keywords: IFRS, BM-SMK, Accounting.

\section{INTRODUCTION}

Accounting is a field of applied science that is used to see the financial existence of both the state, agencies, companies and organizations and others. Accounting at this time has a standard in making financial reports on a company, which used to be accounting learning in terms of making financial reporting using the standards used by the United States known as GAAP. And according to the changes and needs of the company since the era of free trade, the standards used in making financial statements must refer to IFRS standards (International Financial Reporting Standards). The creation of a financial report that should follow the standards of PSAK that has been converged to IFRS, meaning that the report adjusts domestic standards to fit IFRS. The benefits that will be obtained with IFRS convergence, namely providing benefits to the comparability of financial statements and increasing transparency.

Accounting education, at all levels, did not escape being the main target of IFRS convergence success programs, (Sigit: 2013). That is why in the world of education also the material taught must be in accordance with the needs of its users in the field. As well as vocational high school students are expected to be able to use and follow the changes that occur in the business world, in existing standard changes not only can be used in learning in higher education but can be used in the vocational school. Moreover, in education an educational curriculum is link-and-match with the needs of the workforce. (Yevi: 2015) With the existence of a link-and-match curriculum, it is expected that graduates of students from vocational schools must be ready to use in the world of work. That is why accounting subjects provided by teachers at the level of education of vocational schools in accounting majors are so important in their teaching that they follow accounting standards based on generally accepted financial standards. This is because the vocational high school students majoring in accounting as soon as they graduate, they will be ready to enter the world 
of work, both within the company and those engaged in micro and small enterprises (MSMEs). That is why in the world of education in vocational high schools must implement this link and match. Link and match is a policy of the department of education and culture to be able to develop and improve the relevance of vocational high schools (SMK) to the needs of the world of work, business and industry. Therefore the BM Vocational School, especially the Accounting Department, must be prepared to give birth to students who are ready to use in the world of work, so the accounting lessons provided must be in accordance with the needs of the work world, so that the school can provide material accounting related to the current financial accounting standards. The current standard that is in accordance with accounting material is to use a standard, namely the Statement of Accounting Standards (PSAK) of IFRS convergence.

\subsection{IFRS AND SAK-ETAP}

The process of producing financial information for an organization for various parties who need it cannot be done according to everyone's tastes and is different from one another. The process of generating financial information is regulated according to the standards that become a common benchmark used by managers of organizations in certain regions of the country. In Indonesia, the benchmark was compiled by the Indonesian Institute of Accountants (IAI) and was named the financial accounting standard (SAK). Since 2012, SAK has been divided into two types of standards, namely:

\subsection{SAK - IFRS}

These financial accounting standards are structured by adapting from IFRS (International Financial Reporting Standards). This SAK is prepared and intended for organizations that have public accountability. Therefore, every business entity that has public accountability must use this standard. Every business entity has public accountability. The entity is considered to have significant public accountability if it has the following characteristics:

1. The entity has submitted a registration statement, or in the process of submitting a registration statement, to capital market authorities or other regulators for the purpose of securities (securities) issuance in the capital market.

2. The entity controls assets in a fiduciary capacity for a large group of people, such as banks, insurance entities, brokers and / or securities traders, pension funds, mutual funds, and investment banks.

Accounting standards that apply in Indonesia consist of four standards, often referred to as the four pillars of accounting standards, namely: Financial Accounting Standards (SAK), Financial Accounting Standards Entities without Public Accountability (SAK-ETAP), Islamic Financial Accounting Standards (SAK-Syariah), and Government Accounting Standards (SAP). Each standard has different characteristics and uses both in terms of the entity, accounting treatment, and how to use it.

\subsection{STAY-STILL (Entity without public accountability)}

Financial accounting standards for entities without public accountability (SAK - ETAP) are intended to be used by entities without public accountability. Entities without public accountability are entities that:

a. Do not have significant public accountability: and

b. Publish general purpose financial statements for external users.

Financial accounting standards (SAK) that have been previously determined and used are more based on regulations. Almost all SAKs contain detailed rules for various matters and accounting issues. As a result, the longer the SAK will be thicker in line with the more complex accounting environment. In contrast to various accounting standards that have been previously set, SAK-IFRS is based on accounting principles. So, accounting practitioners work based on general acceptable accounting principles (PABU). Although there are still regulations in SAK-IFRS, they have not been as detailed as the rules in the previous SAK.

Entity Accounting Standards without Public Accountability (SAK-ETAP) are used for entities that do not have significant public accountability in the preparation of general-purpose financial statements (general purpose provincial statement). ETAP standards are simpler and there are not many changes to the current accounting practices. Examples of simplifications in the ETAP standard are as follows:

1. There is no comprehensive income statement. The effect of comprehensive income is presented in the statement of changes in equity or equity component in the statement of financial position.

2. Valuation for fixed assets, intangible assets and investment property after the acquisition date uses only the cost of acquisition, there is no choice to use the revaluation value or fair value.

3. There is no recognition of liabilities and deferred tax assets, tax expense is recognized at the amount of tax according to the tax provisions.

Entities that use SAK ETAP in their audit financial statements mention the entity's financial statements in accordance with SAK ETAP. The use of SAK ETAP will make it easier for entities that do not have significant public accountability to prepare financial statements because SAK ETAP is easier and simpler. However, some parties argue 
that the use of the term ETAP gives the impression that the entity does not have accountability. Even though all entities must have accountability to the public, the level of accountability is different. This standard can be effectively used for financial statements for 2009. Entities that meet criteria using ETAP in 2011 must choose to use SAK ETAP or PSAK. If in 2011 still using the PSAK, the following year must be consistent in using the PSAK and may not change using SAK ETAP.

\section{RESEARCH METHOD}

This research is descriptive research, and the method used in this research is descriptive exploratory method using primary and secondary data. The design of this study is:

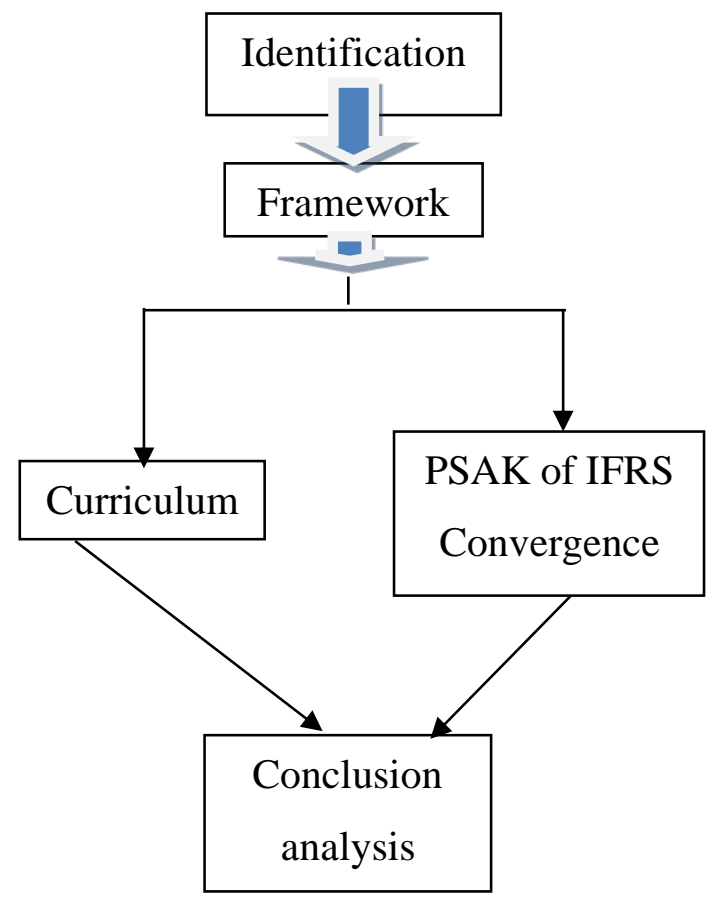

Figure 1. Research design.

The technique of data collection is done by field studies conducted by giving questions or interviews to teachers in the field of study, as well as documentation. Adjust and search for data, for example subject syllabus and accounting curriculum, also observe the learning process and the results will be described. The methods and techniques used consist of the analysis phase and description and the end result is a phenomenological description.

\section{DISCUSSION RESULT}

There are several indicators in this study to see the application of accounting using IFRS standards or Etap SAK. Based on the data that has been obtained, the data will be analyzed with the following indicators:

a. Department support indicators

And almost all schools, both the department head and the school have not prepared about the supporting suggestions and infrastructure of standard accounting material based on IFRS convergence PSAK in terms of supporting departments, this is because there is no understanding of the accounting for IFRS convergence standards. So far, almost none of the vocational schools in Langkat district have tucked into learning about the standard IFRS convergence PSAK in the curriculum, due to the lack of training on this matter and the absence of supporting books and facilities and infrastructure in IFRS-based accounting learning.

\section{b. Indicator of understanding}

The understanding of accounting department teachers at the BM department of accounting in Langkat Regency regarding accounting material that is based on IFRS Convergence PSAK does not yet understand and is familiar with it, because the accounting teacher boards do not know and often hear about the IFRS standard, and moreover understanding material that is.

c. Indicator of teaching coverage

The following is the scope of teaching in financial reporting pembutan based on IFRS convergence PSAK that was examined in this study: 
Table 1.

Teaching coverage in financial reports based on IFRS convergence PSAK.

\begin{tabular}{|c|c|}
\hline $\begin{array}{c}\text { Simple Financial } \\
\text { Statements }\end{array}$ & $\begin{array}{c}\text { of Financial Statements } \\
\text { based on IFRS } \\
\text { convergence PSAK }\end{array}$ \\
\hline R / L & $\begin{array}{c}\text { report Comprehensive } \\
\text { income statement }\end{array}$ \\
\hline Capital Change & $\begin{array}{c}\text { Report Reports of } \\
\text { changes in equity }\end{array}$ \\
\hline Balance Sheet & $\begin{array}{c}\text { Report Financial } \\
\text { position report }\end{array}$ \\
\hline Cash Flow & $\begin{array}{c}\text { Statement Cash flow } \\
\text { statement }\end{array}$ \\
\hline & $\begin{array}{l}\text { Notes to financial } \\
\text { statements }\end{array}$ \\
\hline
\end{tabular}

The conclusion of the table above is through a questionnaire given to accounting teachers, almost all accounting teachers in the district of Langkat teach it to students or students still use it with learning materials that are ordinary or simple standards not based on IFRS convergence based learning material, things This is because there is no demand from the school to apply learning material using IFRS convergence PSAK.

d. Individual readiness indicator

In this study teacher readiness was seen from three indicators, namely (1) Availability of IFRS teaching materials, (2) Reference books, and (3) Training that had been obtained. On this indicator, it can be concluded that the accounting teacher boards have no availability of teaching, reference books that are in accordance with PSAK, and training has never been provided by the school, service or other institutions about accounting learning in making financial reports in accordance with PSAK standards. But they are all accounting teachers ready to receive training or socialization about the new implementation in order to create learning materials that link and match.

In addition, human resources play an important role in the learning process. Teachers who are ready to deliver material will influence students' understanding in accepting classroom learning. Although IAI has converged IFRS into PSAK since 2012, the practice of IFRS still raises many pros and cons in the world of education. So in order to obtain good and quality graduates, it is better for schools to insert about accounting standards-based learning material PSAK IFRS convergence into accounting learning material, both in the basic accounting and financial accounting subjects.

In the accounting school Vocational School that was examined in Langkat Regency, almost all of the schools used the revised K-13 curriculum in 2017. The Public and Private High School curriculum in the district of Langkat in the SMK majoring in accounting specifically used the K-curriculum. 13 revisions 2017, which consisted of three subject groups namely normative, adaptive, and productive. Normative consists of Religious Education, Citizenship Education, Indonesian Language, Sports and Health Jasmasni Education, and Cultural Arts. Adaptive consists of Mathematics, English, Science, Social Sciences, KKPI and Entrepreneurship. While productive only consists of two subjects namely Basic Vocational Competence and Vocational Competence.

\section{CONCLUSION}

On the four indicators, it can be concluded that all accounting teachers in Langkat Regency teach them to students or students still use it with learning materials that are ordinary or simple standards not based on learning material based on IFRS convergence PSAK, this is due to their lack of understanding about the new material is about the Etap SAK standard (IFRS) because they have not yet received socialization about the standard and there is no demand from the school to apply learning material using IFRS convergence PSAK.

The Public and Private Secondary School curriculum in Langkat district in the Vocational School majoring in accounting specifically uses the 2017 revised K-13 curriculum, which consists of three subject groups namely normative, adaptive, and productive. Normative consists of Religious Education, Citizenship Education, Indonesian Language, Sports and Health Jasmasni Education, and Cultural Arts. Adaptive consists of Mathematics, English, Science, Social Sciences, KKPI and Entrepreneurship. While productive only consists of two subjects namely Basic Vocational Competence and Vocational Competence. And in productive subjects they should be able to incorporate the standards used in the learning material by adopting the Etap SAK standard (IFRS), but in reality they have not included these standards in their learning material due to their lack of understanding and lack of socialization. or direction from the education office itself. 
And in fact, accounting teachers can incorporate accounting learning by using the IFRS convergence standard, but because the teacher boards have never been given socialization, especially training on accounting learning material in the preparation of financial statements using IFRS (SAK Etap) convergence PSAK. That is why the teachers have not inserted or included it in the learning process.

\section{BIBLIOGRAPHY}

Armstrong, C. S., Barth, M. E., Jagolinzer, A. D., Riedl, E. J., 2007. Market

Bisker, Limbong. 2012. Analysis of the Effect of Availability of Infrastructure and Education Facilities on the Implementation of Educational Quality Guarantor and the Impact on Quality of Education Results: Cases in Junior High Schools in Singkawang City, West Kalimantan Province. Thesis. Indonesian education university.

Description ".http: //natawidnyana-wordpress.com.http: //ssrn.com/abstract=903429.

Dwi Martani, et al. 2012. Intermediate Financial Accounting I and II Based on IFRS Convergence PSAK. Issue 2 Book 1. Salemba Four Publishers.

Mulyasa. 2004. School Based Management. Bandung. PT. Rodokarya teenager

Natawidnyana, 2008. "International Financing Reporting Standards: A Brief

Nining. 2013. Impact of IFRS Implementation on Accounting Education in Indonesia. reaction to the adoption of IFRS in Europe. Available at SSRN:

Risma. 2015. Readiness of Lecturers of the Department of Accounting in the State University of Yogyakarta and Facing the Convergence of the International Financial Reporting Standars. Essay. Yogyakarta State University.

Rudianto. 2012. Introduction to Accounting Concepts and Techniques for Making IFRS Adaptation Financial Statements. Erlangga Publisher. Jakarta.

Sigit, et al. 2013. Analysis of Readiness and Implementation of Accounting Lectures Based on Convergence of International Financial Reporting Standards (IFRS). Journal of Accounting Education, Vol. 1.No.4. 2013. IIN 2089-7952

Yevi, et al. 2015. Impact of Convergence of International Financial Reporting Standards (IFRS) on Accounting Learning at Private Universities in Bandar Lampung City. Darmajaya Business Journal, Vol.01. No.02, July 2015.

Yuningsih. 2015. Understanding of Accounting Students Against International Financial Reporting Standards (IFRS). Thesis. Satya Wacana Christian University. 